Socio-economic problems of management: Collective monograph. - Thorpe-Bowker ${ }^{\circledR}$ Melbourne, Australia, 2015. - C. 107-122.

13.

Лопатин

Иллюстрированный толковый словарь современного русского языка / В.В. Лопатин, Л.Е. Лопатина - М.: Эксмо, 2007. - $976 \mathrm{c}$.

14. Гетьман

О.А.Определение закономерностей между построением структуры и организационной эффективностью работы организации / О.А. Гетьман // Вісник економіки транспорту і промисловості. - Х. - 2014. № 47. - C. 70-76.

15. Андреева T.Е. Основные подходы к разработке математической модели определения влияния факторов сложности и динамичности внешней среды предприятия в формате перспектив его развития [Електронний ресурс] / Т. Е. Андреева, О. А. Гетьман // Економіка. Управління. Інновації. - 2015. - Вып. 1 (13). - Режим доступу до журн. http://www.nbuv.gov.ua/

УДК 69.00:65.012

\title{
УПРАВЛІННЯ КОНКУРЕНТОСПРОМОЖНІСТЮ БУДІВЕЛЬНИХ ПШДПРИЕМСТВ ЗАЛІЗНИЧНОГО ТРАНСПОРТУ
}

\author{
Боровик Ю.Т., к.е.н., доцент (УкрДУЗТ)
}

У статті досліджено фактори впливу на конкурентоспроможсність підприємства та визначено основні сфери управління конкурентоспроможністю будівельних підприсмств і організацій залізничного транспорту. Визначено організачійні заходи, які спрямовані на підвищення конкурентоспроможності будівельного підприємства.

Запропоновано маркетинговий механізм управління конкурентоспроможністю будівельних підприємств залізничного транспорту. Досліджено специфіку будівельних підприємств залізничного транспорту.

Ключові слова: конкурентоспроможнність, будівельні підприємства залізничного транспорту, фактори конкурентоспроможності, маркетинговий механізм управління конкурентоспроможністю.

\section{УПРАВЛЕНИЕ КОНКУРЕНТОСПОСОБНОСТЬЮ СТРОИТЕЛЬНЫХ ПРЕДПРИЯТИЙ ЖЕЛЕЗНОДОРОЖНОГО ТРАНСПОРТА}

\author{
Боровик Ю.Т., к.э.н., доцент (УкрГУЖТ)
}

В статье исследованы факторы влияния на конкурентоспособность предприятий u определень основные сферы управления конкурентоспособностью строительных предприятий и организаций железнодорожного транспорта. В результате усиления конкуренции актуальной становится задача повышения конкурентоспособности строительных предприятий. Этим объясняется необходимость глубокого изучения различных подходов ученых к вопросу классификации факторов конкурентоспособности предприятия. 
В статье определены организационные мероприятия, направленные на повыпение конкурентоспособности строительных предприятий. Предложено маркетинговый механизм управления конкурентоспособностью строительных предприятий железнодорожного транспорта, который состоит из четырех основных компонентов: конкурентоспособность продукиии предприятия; конкурентоспособность бренда предприятия, конкурентоспособность предприятия и конкурентоспособность потенциала предприятия.

Исследовано особенности строчтельной отрасли, включая специффику железнодорожного строительства.

Ключевые слова: конкурентоспособность, строительные предприятия жсллезнодорожного транспорта, факторы конкурентоспособности, маркетинговый механизм управления конкурентоспособностью.

\title{
CONTROL OF COMPETITIVENESS OF BUILDING ENTERPRISES OF RAILWAY TRANSPORT
}

\author{
Borovik Y.T., Ph. D., associate Professor (USURT)
}

In the article factors of influence on the competitiveness of enterprises are investigated and the main spheres of management of competitiveness of construction enterprises and organizations of railway transport are determined. As a result of increased competition, the task of increasing the competitiveness of construction companies becomes urgent. This explains the need for in-depth study of various approaches of scientists to the issue of classification of factors of enterprise competitiveness.

The article defines organizational measures aimed at increasing the competitiveness of construction companies. A marketing mechanism for managing the competitiveness of railway construction enterprises is proposed, which consists of four main components: the competitiveness of enterprise products as the basic basis for its development; the brand's competitiveness; the competitiveness of the enterprise and the competitiveness of the enterprise's potential, that is, the ability to work in the market in the long term, successfully adapt to changing conditions and environmental factors, preserve existing and create new competitive advantages.

The features of the construction industry, including the specifics of railway construction, are explored.

Keywords: competitiveness, construction enterprises of railway transport, factors of competitiveness, marketing mechanism of competitiveness management.

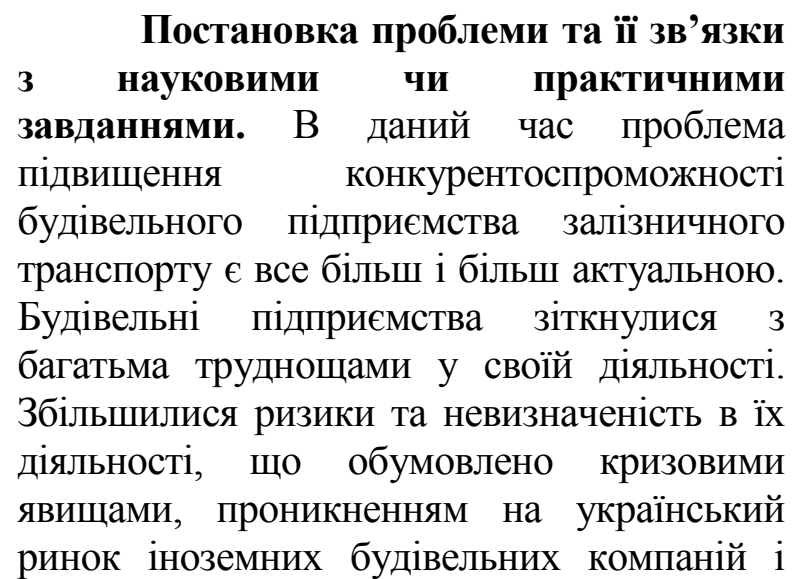

виникненням нових, вітчизняних компаній на будівельному ринку.

Сучасні умови, в яких здійснюють свою діяльність будівельні підприємства в Україні характеризуються і тим, що все сильніше заявляє про себе конкуренція, яка є рушійною силою розвитку суспільства, головним інструментом економії ресурсів i підвищенням якості товарів. У зв'язку з цим для будівельної галузі $\epsilon$ актуальною проблема підвищення конкурентоспроможності, адже безпосередньо

Вісник економіки транспорту і промисловості № 59, 2017 
конкуренція розвиває будівництво. Саме через низьку конкурентоспроможність припиняють свою діяльність не відповідають вимогам ринку підприємства та організації й залишаються функціонувати та розвиватися тільки конкурентоспроможні будівельні підприємства.

Таким чином, розвиток конкурентних відносин і відповідно управління конкурентоспроможністю будівельних підприємств i організацій залізничного транспорту $\epsilon$ основою розвитку будівельного ринку в країні.

Аналіз останніх досліджень i публікацій та виділення невирішених частин загальної проблеми. Дослідження управління конкуренто-спроможністю будівельних підприємств $\epsilon$ одним 3 основних пріоритетів економічної науки. Багато вітчизняних та закордонних вчених присвятили свої праці вивченню аспектів конкурентоспроможності підприємств в умовах кризи. Це такі дослідники як Дикань В.Л.[3-5], Портер М.[8], питанням вивчення факторів конкурентоспроможності будівельних підприємств присвячені роботи: Асаула А.Н.[1], Беттса М.[12], Верхоглядовой Н.I.[2], Свтєєвой В.Г.[6], Россіхіной О.С.[9], Самошина О.Г. [10], Смачило В.В.[11]. Недослідженим залишається питання управління конкурентоспроможністю будівельних підприємств залізничного транспорту 3 урахуванням специфіки галузі.

Метою статті $\epsilon$ вивчення окремих теоретичних підходів управління конкурентоспроможністю будівельних підприємств залізничного транспорту 3 використанням методів маркетингу.

Викладення основного матеріалу. Галуззю, яка дуже чутливо реагує на стан економіки країни - $\epsilon$ будівельний комплекс. У будівництві найперше відчувається фаза економічного зростання саме, знаходячи своє втілення в обсягах інвестиційних капіталовкладень, що швидко зростають, у виконання будівельних робіт. У фазах стагнації та економічної кризи темпи падіння обсягів будівництва є одними із найбільших серед інших галузей економіки. Це переконливо підтверджується статистичними даними щодо обсягів падіння будівельної галузі в Україні під час кризи 2008-2009 років. У теперішній час в Україні відбувається посилення конкуренції, тому керівники будівельних організацій повинні знаходити нові інструменти управління підприємствами та важелі підвищення їх конкурентоспроможності. Для забезпечення конкурентних переваг необхідно виявити ті фактори, які впливають на відношення споживачів до підприємства та його продукції, та на цій основі розробити адекватну умовам зовнішнього середовища програму забезпечення конкурентоспроможності підприємства.

Будівельний комплекс - складається iз таких основних блоків як виробництво будівельних матеріалів, власне будівництво, будівельне машинобудування та проектноконструкторські та дослідні роботи в галузі будівництва. Частка будівельного комплексу в національній економіці досить значна (в Україні питома вага в ВВП тільки будівництва становить 8\%), комплекс охоплюе майже $10 \%$ усіх зайнятих в національній економіці: 3 них 6\% власне у будівництві, $3 \%$ - у галузі виробництва будівельних матеріалів. Будівельний комплекс також тісно пов'язаний $з$ іншими галузями економіки, за його участю створюється значна частина основних виробничих та невиробничих фондів. 3 іншого боку, комплекс $\epsilon$ споживачем продукції багатьох галузей: будівництво використовує $\quad 10 \% \quad$ продукції машинобудування, $20 \%$ прокату чорних металів, 40\% лісоматеріалів, споживає вироби хімічної промисловості [7].

Організаційними заходами, які спрямовані на підвищення конкурентоспроможності будівельного підприємства, можуть бути:

- забезпечення техніко-економічних i якісних показників, які створюють 
пріоритетність продукції підприємства на ринку;

- зміна якості виробу і його технікоекономічних параметрів 3 метою більш повного врахування вимог споживача;

- виявлення і забезпечення переваг продукту в порівнянні 3 замінниками; виявлення переваг і недоліків товаріваналогів, які випускаються конкурентами та використання цих результатів;

- визначення можливих модифікацій

продукту шляхом підвищення якісних характеристик;

- виявлення і використання цінових факторів конкурентоспроможності підвищення

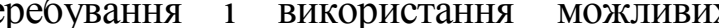
пріоритетних сфер застосування продукції, особливо інноваційної;

- диференціація продукції.

Забезпечення

конкурентоспроможності будівельних підприємств залізничного транспорту має відбуватись внаслідок функціонування ефективного маркетингового механізму управління нею. Для чіткого відокремлення впливу маркетингових чинників на конкурентоспроможність підприємства можливо побудувати модель конкурентоспроможності, яка складається із таких основних компонентів: конкурентоспроможності продукції підприємства; конкурентоспроможності торгової марки; конкурентоспроможності самого підприємства як організаційноекономічної системи

конкурентоспроможності потенціалу підприємства, що виявляється у його здатності функціонувати на ринку у довгостроковій перспективі, успішно адаптуватись до зміни умов i чинників зовнішнього середовища, підтримувати конкурентні переваги, що існують та формувати нові.

Основу конкурентоспроможності організації у ринковому середовищі формує конкурентоспроможність його продукції, що характеризує іiї здатність задовольняти

краще, ніж конкуренти, потреби споживачів, пропонуючи їм унікальні властивості продукції та оптимальне співвідношення «ціна-якість».

$$
\text { Другим рівнем моделі }
$$

конкурентоспроможності суб'єкту, що господарює, $€$ конкурентоспроможність торгової марки, що формує здатність протидіяти конкурентам та залучати споживачів на довготривалій основі. Конкурентоспроможна продукція $\epsilon$ передумовою формування конкурентних переваг торгової марки й в процесі управління конкурентоспроможністю торгової марки визначальне місце займає саме маркетинг, а саме - політика підприємства у сфері реклами, комунікацій, формування іміджу та брендингу.

Виробництво й реалізація конкурентоспроможної продукції обов'язкова умова конкурентоспроможності підприємства як організаційно-економічної системи, що розглядається як здатність виробляти та реалізовувати конкурентоспроможну продукцію за високого рівня обслуговування, можливість ефективно розпоряджатися наявними матеріальними, трудовими, фінансовими та інформаційними ресурсами на певних ринках в конкретний проміжок часу. Одним з основних маркетингових чинників формування конкурентоспроможності будівельного підприємства на цьому рівні $є$ маркетингова збутова політика, оскільки чітка i налагоджена робота каналів розподілу продукції є запорукою успішного розвитку економіки будь-якої країни.

На вищому рівні конкурентоспроможності суб'єктів господарювання знаходиться конкурентоспроможність потенціалу підприємства, що формує основу для його успішного функціонування у довготривалій перспективі.

механізмі

Важливе значення в маркетинговому

конкурентоспроможністю управління

підприємств залізничного будівельних транспорту

Вісник економіки транспорту і промисловості № 59, 2017 
належить підсистемі моніторингу зовнішнього середовища, що здійснює ретельне відстеження зовнішніх чинників впливу на конкурентоспроможність будівельних підприємств та формує інформаційний базис, на основі якого функціонує підсистема адаптації маркетингового потенціалу підприємства до умов середовища.

В умовах несприятливого зовнішнього середовища істотні зміни відбуваються у технологіях та методах ведення господарської діяльності підприємств будівельної сфери, що використовують провідні міжнародні компанії, які зокрема стосуються таких функціональних компонентів господарського механізму підприємств як загальні організаційно-управлінські бізнеспроцеси, бізнес-процеси управління техніко-технологічним підприємств, бізнес-процеси управління маркетингом і збутом будівельної продукції, бізнес-процеси управління операційною діяльністю підприємства. В сучасних умовах успішне функціонування підприємств будівельної галузі в Україні практично неможливе без розробки та впровадження маркетингових механізмів управління конкурентоспроможністю та адаптації підприємств до нових умов зовнішнього господарського середовища.

Іншим компонентом маркетингового механізму управління конкурентоспроможністю будівельних підприємств $€$ підсистема адаптації маркетингового потенціалу підприємства до умов зовнішнього середовища, яка реалізується через розробку маркетингової стратегіï, формування організаційноуправлінської та інформаційної інфраструктури маркетингової діяльності підприємства, а також проектування елементів його маркетингового комплексу.

Маркетингова стратегія визначає загальні напрями та базові принципи адаптації маркетингового потенціалу підприємства до умов зовнішнього середовища, а іï практичне втілення відбувається шляхом використання будівельними підприємствами відповідного маркетингового комплексу. Специфіка будівельного маркетингу полягає у чіткій спрямованості його складових на основний орієнтир ринку для досягнення результатів та збалансованому використанні потрібного набору маркетингових інструментів. Для будівельного ринку є характерними швидкі зміни у технологіях та високі вимоги до рівня технологічності пропонованих на цих ринках товарів. Для учасників промислових ринків важливого значення набуває активна інноваційна політика, спрямована як на розробку принципово нових товарів, так і на постійне удосконалення технологій виробництва будівельних матеріалів, що існують. Дослідження показують, що нові матеріали та технології створюються i виводяться на будівельний ринок безупинно, при цьому найбільшу активність виявляють іноземні виробники будівельних матеріалів.

Забезпечення ефективного функціонування та розвитку підприємств будівельної галузі в сучасних умовах вимагає від них постійних еволюційних зусиль в напрямку вдосконалення структури управління, розширення ринків збуту, підвищення якості продукції та послуг, розробки інвестиційної та інноваційної політики, за умов врахування максимальної кількості чинників мікро- та макросередовища.

Будівництво $є$ базовою сферою економіки будь-якої держави, від ефективності функціонування та темпів розвитку підприємств якої залежить рівень розвитку багатьох інших галузей.

Будівництво за своїми технічними, організаційними та економічними характеристиками об’єктивно відрізняється від інших галузей матеріального виробництва.

Продукцією будівництва є повністю закінчені та прийняті замовником об'єкти. Продукт капітального будівництва, на 
відміну від інших галузей, має низку особливостей, які визначаються:

a) технічними особливостями будівельної продукції;

б) особливостями будівельного виробництва;

в) організаційно-економічними особливостями галузі.

Вплив особливостей продукту на економіку капітального будівництва полягає у наступному:

a) вплив технічних особливостей будівельної продукції на економіку будівництва:

непорушність будівельної продукції приводить до необхідності пересувного характеру роботи виконавців будівельних робіт. У будівництві переміщаються люди та знаряддя праці, а не предмети праці як в промисловості. 3'являється необхідність у додаткових витратах на тимчасові споруди й т.п.;

- великі розміри продукції, їх складність i багато детальність, матеріаломісткість визначають високу питому вартість матеріалів і конструкцій (до 50-60\% загальних витрат);

будівельна продукція $\epsilon$ капіталомісткою, що вимагає великих капіталовкладень. Звідси важливість обгрунтування цих витрат, висока роль кредитів серед джерел фінансування будівництва;

$$
\text { індивідуальний }
$$

споруджуваних об'єктів

характер особливості ціноутворення на будівельну продукцію;

- тривалий термін служби будинків і споруд визначає високий рівень морального зносу будівельної продукції;

б) вплив особливостей будівельного виробництва на економіку капітального будівництва полягає у такому:

- загальна тривалість будівельного циклу визначає утворення великих розмірів незавершеного виробництва, поява фінансових розрахунків за етапи та комплекси робіт, необхідність страхування від стихійних лих і т.п.;

- будівельні роботи здебільшого виробляються на відкритому повітрі, що викликає появу "сезонності", має наслідки, наприклад, зимове подорожчання тощо;

- різне розташування будівельних об'єктів і пересувний характер виконавців будівельних робіт визначає високу питому вагу в структурі основних фондів будівництва, транспортної техніки; специфічні конструктивні особливості будівельної техніки; необхідність мати велику кількість тимчасових або пересувних споруд;

- хід будівництва суттєво залежить від місцевих умов: розвитку мережі доріг, наявності близько розташованих підприємств 3 виробництва матеріалів i конструкцій і т.п. Навіть однакові об'єкти зводяться по-різному в різних регіонах i навіть у районах одного регіону;

- будівельники не тільки будують, вони зобов'язані й освоїти створені потужності (запустити інфраструктуру об'єкта, комунікації тощо);

в) вплив організаційно-економічних особливостей будівництва на економіку галузі визначається наступними чинниками:

- будівництво здійснюється "на замовлення" i дуже рідко на продаж. У цьому відношенні будівництво й досі залишається ремеслом;

- у будівництві одного об'єкта беруть участь декілька підприємств, що викликає створення особливих організаційних форм в управлінні будівництвом (генпідрядники, підрядники, замовники тощо);

- конструктивна складність будівельних об'єктів і різноманіття господарських зв'язків будівництва 3 іншими галузями виражається в необхідності використання тисяч видів матеріалів, конструкцій і послуг інших галузей;

- ступінь освоєння території в чому визначає витрати на будівництво, тому додаткові витрати (на 
інфраструктуру) можуть перевищувати власне будівельні витрати в кілька разів; необхідність комплексного будівництва промислових об'єктів визначається неможливістю функціонування, наприклад, промислових будівель без складського господарства, інженерних мереж і т.п.;

\section{будівельнику}

доводиться враховувати та знати технологічні особливості тих галузей, для яких ведеться будівництво.

Залізничне будівництво - найбільш складне серед інших видів капітального будівництва, дуже специфічне із-за своєї значної лінійної протяжності. Воно здійснюється у різних кліматичних умовах та інженерно-геологічних умовах, просто неба, цілий рік, з використанням мобільної техніки та ведеться звичайно мало обжитих районах. До залізничного будівництва відносяться: споруда нових та з'єднувальних колій, спорудження других і третіх колій, електрифікація залізниць, що існують, та знову споруджуваних, реконструкція i перебудова окремих ліній. Роботи на залізницях, що існують, виробляються в умовах безперервного руху поїздів.

Усі роботи з будівництва залізниць за характером їх розподілу по трасі діляться на два види: зосереджені та розподілені.

Зважаючи на специфіку будівельної галузі можна розглядати розвиток підприємства в таких аспектах: інноваційна складова розвитку; економічна складова розвитку; техніко-технологічна складова розвитку; організаційна складова розвитку.

Нестабільність $є$ характерною ознакою розвитку будівельного підприємства залізничного транспорту, як стан відкритої системи при якому відбувається зміна іï складу, структури та поведінки. Процес розвитку відбувається під впливом зовнішніх та внутрішніх чинників, разом $з$ тим система має постійно функціонувати, щоб зберегти умови свого існування.
Фактори зовнішнього та внутрішнього середовища підприємства знаходяться у взаємодії, формуючи певні об'єктивні умови його розвитку.

Непрямий вплив на розвиток будівельного підприємства здійснюють групи фактори так званого макросередовища. До них слід віднести політичні, екологічні, соціокультурні, демографічні, макроекономічні, науковотехнічні.

Специфіка будівельних ринків накладає певні обмеження на можливості варіювати каналами збуту продукції. Попит на будівельну продукцію носить похідний (вторинний) характер i похідним (вторинним) він $є$ тому, що виникає не сам по собі, а внаслідок попиту на товари, будівельні роботи та послуги, для виготовлення чи надання яких потрібна будівельна продукція. У загальному випадку - попит на будівельну продукцію залежить від загального рівня економічного розвитку в країні.

Висновки. Стратегія конкурентоспроможності та інвестиційної привабливості будівельного підприємства залізничного транспорту $\epsilon$ взаємодоповнюючими та у тісній взаємодії цих двох факторів можливо забезпечити не лише виживання підприємства, але і його постійний розвиток.

Виходячи із розглянутого, розробка практичних рекомендацій для вирішення питань організації управління розвитком будівельних підприємств залізничного транспорту та вивчення ряду проблем, пов'язаних 3 критеріями формування стратегії розвитку підприємства визначає завдання для подальшого дослідження.

\section{ПЕРЕЛІК ВИКОРИСТАНИХ ДЖЕРЕЛ}

1. Асаул А.Н. Маркетингменеджмент в строительстве: под редакцией д.э.н., профессора, Заслуженного строителя РФ А.Н. Асаула / А.Н. Асаул, В.П.Грахов. СПб.: «Гуманистика», 2007. - 248 с. 
2. Верхоглядова Н.I., КоваленкоМарченкова. конкурентоспроможності Оцінка будівельної галузі України/ наукове фахове видання економіка", № 3, http://www.economy.nayka.com.ua/?op=1\&z= 5471

3. Данько M.I. Забезпечення конкурентоспроможності промислових підприємств в умовах міжнародних транспортних коридорів: Монографія/ M.I. Данько, В.Л.Дикань, Н.В. Якименко. Харків: УкрДАЗТ, 2008. - 170с.

4. Дикань В.Л. Реформирование экономики Украины

конкурентоустойчивость предприятий: Монографія/ В.Л.Дикань. - Харьков: Основа, 1997. - 350 с.

5. Дикань В.Л. Забезпечення конкурентоспроможності підприємств. Підручник / В.Л.Дикань, Ю.Т.Боровик, О.М. Полякова, Ю.М. Уткіна. - Харків: УкрДАЗТ, 2012. - 415с.

6. Свтєєва В. Г. Маркетинг як інструмент конкурентоспроможності будівельного підприємства на ринку житла України/ "Ефективна економіка", № 8, 2013/ [Электронный ресурс] - Режим доступа. http://www.economy.nayka.com.ua/?op=1\&z= 2243

7. Основні показники соціальноекономічного розвитку України/ [Електронний ресурс]. - Режим доступу : http://www.ukrstat.gov.ua/

8. Портер М. Международная конкуренция: конкурентные преимущества стран: Пер. с англ. / Под ред. В.Д. Щетинина. - М.: Международные отношения, 1993. - 896 с.

$$
\text { 9. Россіхіна О.С. }
$$

Конкурентоутворюючи фактори, як основа стратегіï конкуренції будівельного підприємства / Россіхіна О.С. // Международные конференции: Стратегії інноваційного розвитку економіки України проблеми, перспективи, ефективність. Секція 2. Економіка підприємства та маркетинг. - НТУ «ХПИ», 2010. / [Электронный ресурс] - Режим доступу: http://www.kpi.kharkov.ua/ archive/Conferences/Стратегіï\%20інноваційн ого $\% 20$ розвитку\% $\% 20$ економіки $\% 20$ України \%20проблеми,\%20перспективи,\%20ефектив ність/2010/S2/КОНКУРЕНТОУТВОРЮЮЧ И\%20ФАКТОРИ.pdf

10. Самошин А.Г. Повышение конкурентоспособности строительного предприятия // Молодежный научный форум: Общественные и экономичес- кие науки: электр. сб. ст. по материалам XLIV студ. междунар. Заочной науч.-практ. конф.- М.: «МЦНО».-2017 - №4(44)/ [Электронный ресурс] -Режим доступа.URL:https://nauchforum.ru/archive/

MNF_social/4(44).pdf

11. Смачило В.В., ГоловкоМарченко I.C. Фактори конкурентоспроможності будівельних підприємств/ «Молодий вчений» • № 4.4 (44.4) • квітень, 2017 p. http://molodyvcheny.in.ua /files/journal/2017/4.4/23.pdf

12. Betts M. Strategic Management of IT in Construction / M. Betts. - Oxford: Blackwell Science Ltd, 1999. - P. 73-82 